\title{
Paleomagnetism of upper Cretaceous rocks from South China
}

\author{
Dennis V. Kent ${ }^{1}$, G. Xu ${ }^{2}$, K. Huang ${ }^{2}$, W.Y. Zhang ${ }^{2, *}$ and Neil D. Opdyke ${ }^{3}$ \\ 1 Lamont-Doherty Geological Observatory and Department of Geological Sciences, \\ Columbia University, Palisades, NY 10964 (U.S.A.) \\ 2 Academia Sinica, Institute of Geology, Beijing (China) \\ ${ }^{3}$ Department of Geology, University of Florida, Gainesville, FL 32611 (U.S.A.)
}

Received November 30, 1985; revised version accepted April 4, 1986

\begin{abstract}
Paleomagnetic study of upper Cretaceous redbeds from two areas in South China was undertaken in an effort to constrain better the history of tectonic movements in southeastern Asia. From the Nanjing area $\left(32^{\circ} \mathrm{N}, 119^{\circ} \mathrm{E}\right)$, high-temperature characteristic directions which pass a fold test were obtained from ten sites (43 samples) in the upper Cretaceous Puko and Yanzijing Formations. The paleomagnetic pole position $\left(76.3^{\circ} \mathrm{N}, 172.6^{\circ} \mathrm{E} ; A_{95}=10.3^{\circ}\right)$ agrees well with a late Cretaceous reference pole for Eurasia and thus confirms that this part of South China was fully sutured to Eurasia by the end of the Cretaceous with no paleomagnetically resolvable subsequent relative rotation. In western Sichuan $\left(26.5^{\circ} \mathrm{N}, 102.3^{\circ} \mathrm{E}\right)$, high-temperature characteristic directions of normal and reverse polarity were obtained from twelve samples (48 specimens) in the upper Cretaceous to lower Paleocene Xiaoba and Leidashu Formations. A provisional paleomagnetic pole position $\left(80.9^{\circ} \mathrm{N}, 296.8^{\circ} \mathrm{E} ; A_{95}=7.7^{\circ}\right)$ differs significantly from a late Cretaceous Eurasia reference pole. In terms of apparent tectonic movement, the difference in paleopole positions would indicate a $13 \pm 10.3^{\circ}$ northward translation and $22 \pm 11.2^{\circ}$ counterclockwise rotation of western Sichuan relative to Eurasia. Confirmation of this reconnaisance result, which would suggest that western Sichuan was pushed ahead of an impinging India, is needed.
\end{abstract}

\section{Introduction}

It has been proposed that many tectonic features observed in central and southeastern Asia can be understood as direct consequences of the collision of the rigid Indian continent with the southern margin of the Asia continent commencing in the early Tertiary [1,2]. The possibility that continental blocks of eastern Asia have undergone rotation and translation during the Cenozoic can be tested by paleomagnetic studies.

Paleomagnetic constraints on Late Cretaceous and Cenozoic tectonics of southeastern Asia have been recently reviewed by Achache et al. [3]. There is only a single paleomagnetic result for the Cretaceous of South China and it is based on samples not subjected to magnetic cleaning [4]. To contribute additional paleomagnetic constraints, we sampled upper Cretaceous redbeds in two areas in

\footnotetext{
* Deceased February 1985.
}

South China, near Nanjing, Jiangsu Province, and near Huidong, in western Sichuan Province (Fig. 1)

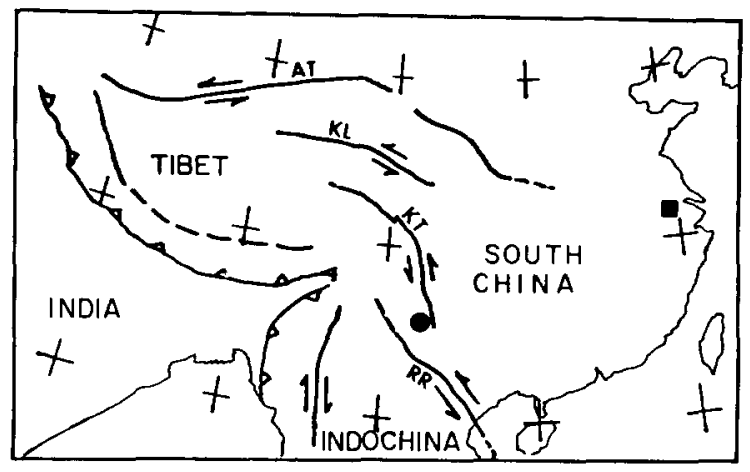

Fig. 1. Sketch map of eastern Asia (traced from [1]) showing major faults ( $A T$, Altyn Tagh; $K L$, Kunlun; $K T$, Kang Ting; $R R$, Red River) and paleomagnetic sampling localities (filled square: upper Cretaceous Puko and Yanzijing Formations near Nanjing city; filled circle: upper Cretaceous to lower Paleocene Xiaoba and Leidashu Formations in western Sichuan province). 


\section{Geological setting and sampling}

Nanjing area. The Cretaceous is well-developed in the Nanjing area where it has a total thickness of up to $3000 \mathrm{~m}$. It is composed primarily of terrestrial facies clastics deposited in fault depressions. The upper Cretaceous of the Nanjing area is divided into two formations: the Puko Formation and the overlying Yanzijing Formation. They are composed mainly of purple-colored sandstones, siltstones and conglomerates but include grey to white-coloured sandstones, siltstones and calcareous mudstones. These deposits contain Crestocypridea fossils which are considered typical fossils of the late Cretaceous.

Major regional unconformities in the late Mesozoic stratigraphy of the Nanjing area exist between the upper Jurassic and lower Cretaceous, and between the lower Cretaceous and upper Cretaceous. An angular unconformity between the upper Cretaceous and Paleogene is not exposed in the immediate vicinity of Nanjing but regional geological data indicate that such an unconformity exists. Therefore the time of deformation and folding of upper Cretaceous rocks was probably the end of the Cretaceous or the early Tertiary.

Sampling of the upper Cretaceous Puko and Yanzijing Formations was done at 10 sites at each of which 5 oriented drill core samples were taken. Bedding attitudes are variable and allow a tilt test.

Sichuan area. A more limited set of samples (one oriented hand sample from each of 17 sites) was also collected from the upper Cretaceous Xiaoba and Leidashu Formations at the northwestern and northern flank of a basin-like syncline located in the bordering area between Huili County and Huidong County, western Sichuan Province. The Leidashu Formation constitutes the core of the syncline while the Xiaoba Formation and Jurassic strata crop out along the flanks. The Xiaoba Formation, disconformably overlying the Jurassic and $1345 \mathrm{~m}$ in thickness at the sampled section, is composed mainly of purplish red mudstones and calcareous siltstones. Copper-bearing conglomerates occur near the base and marly interbeds in the middle part of the formation. Fossils include ostracods such as Cypric sp., Eucypris sp., Cyprinotus sp. and charophytes such as $O b$ tusochara $\mathrm{sp}$. The overlying Leidashu Formation is unconformably overlain by the Neogene Xiqeda Formation, and is composed chiefly of brick-red arkosic quartz sandstones interbedded with calcareous siltstones and mudstones with intercalated marly layers. Fossils include abundant charophytes such as Kosmogyra sp., Tectochara sp., Obtusochara sp. and ostracods such as Darwinnla sp., Limnocythere sp., Eucypris sp., Cypris sp. The Leidashu Formation may span the Late Cretaceous/Paleocene because some important members of the Paleocene charophytes like Limnocythere, Illyocypris and Obtusochara jianglingensis have been discovered in the upper part of the coeval formation (Guankou Formation) in the Sichuan basin, while footprints of Ornithosauria have been found in the lower part of the equivalent formation (Zhaojiadian Formation) in central Yunnan Province [5]. Based on these findings the folding is now believed by some Chinese geologists to have taken place after the Paleocene [6].

\section{Paleomagnetic results}

Nanjing area. The intensities of natural remanent magnetization (NRM) of the Puko and Yanziji redbeds are typically on the order of $10^{-2} \mathrm{~A} / \mathrm{m}$ and therefore presented no difficulty in measurement with a computerized flux-gate spinner magnetometer. The magnetization of these redbeds is dominated by a very high-coercivity magnetic mineral, probably hematite. Consequently, progressive thermal demagnetization at a minimum of 6 levels was used to resolve characteristic components. Examples of orthogonal demagnetograms are shown in Fig. 2a, b.

A component with a direction aligned roughly along the present field (northerly and moderately to steeply down) is typically removed in the initial stages of demagnetization up to treatments of $500-600^{\circ} \mathrm{C}$. Further thermal treatment reveals in most samples a high-temperature component with a demagnetization trajectory that converges toward the origin. The direction of this final high-temperature magnetization (up to $685^{\circ} \mathrm{C}$ ), which we suggest is the characteristic component (ChRM), was determined by principal component analysis [7] on 3 or more data points. Forty-three out of the 50 independently oriented samples measured provided reliable data. One of the rejected 
a.

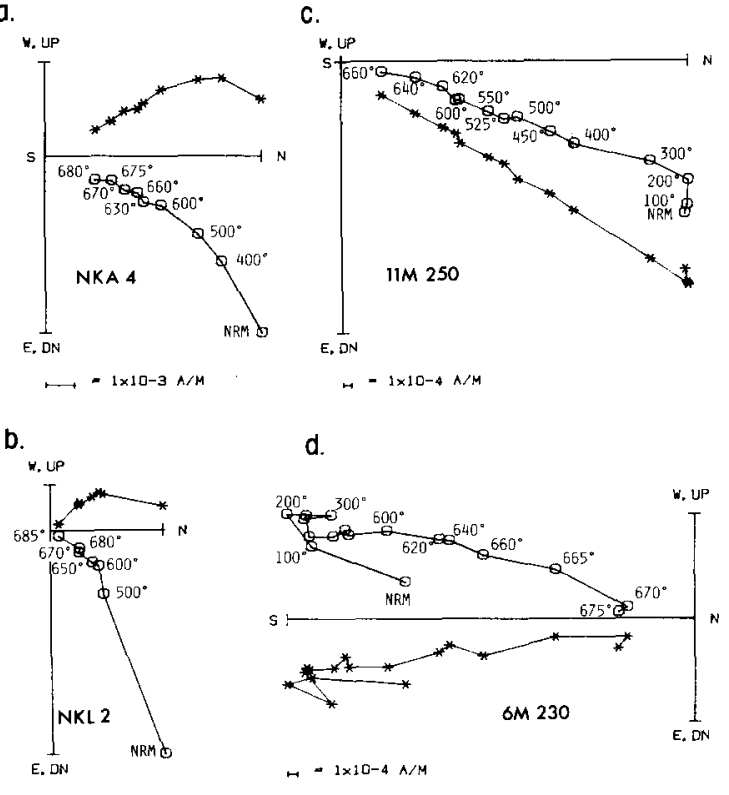

Fig. 2. Vector plots of thermal demagnetization (in Celsius) of NRM of samples from Nanjing area $(a, b)$ and from western Sichuan (c, d). Open circles (stars) plotted on vertical (horizontal) planes in geographic coordinates.

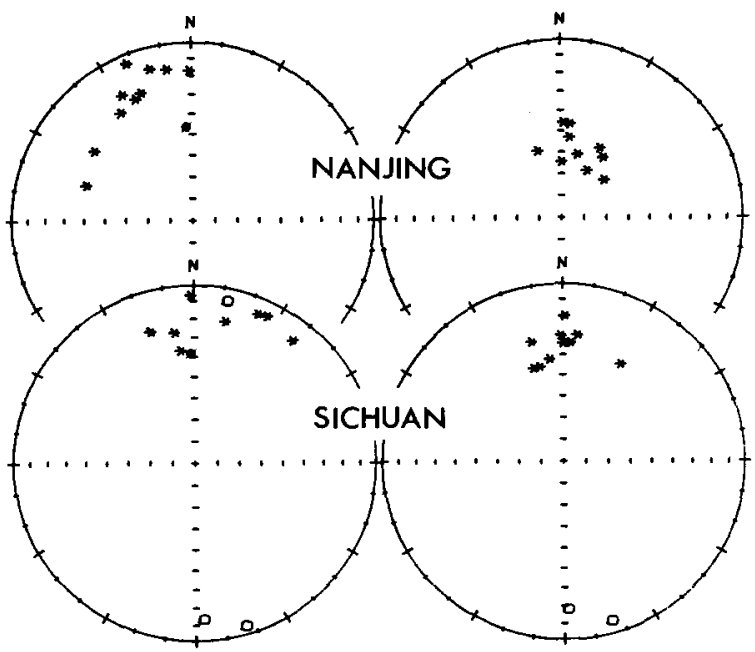

Fig. 3. Site-mean characteristic directions (10 sites) of upper Cretaceous rocks from Nanjing area (top) and sample-mean characteristic directions (12 samples) of upper Cretaceous to lower Paleocene rocks from western Sichuan (bottom), before (left) and after (right) tectonic tilt corrections. Stars and open circles on lower and upper hemisphere, respectively, of equalarea projections. Slashed circle on left is present geomagnetic field direction for each sampling locality. samples had been obviously grossly misoriented, 4 samples gave erratic demagnetization trajectories and no magnetization components could be isolated, and the remaining 2 rejected samples were weakly magnetized and dominated by the present field direction.

The distribution of site-mean ChRM directions (Fig. 3, top) shows that before tilt corrections are made, the ChRM directions are not along the present field but instead tend to be more northwesterly and shallower (mean for 10 sites, $D=$ $\left.333.9^{\circ}, I=23.8^{\circ}, \alpha_{95}=12.8^{\circ}\right)$. This is evidence that these directions are not of recent origin, even though the directions do fall near the present field after tilt corrections are made $\left(D=13.7^{\circ}, I=58^{\circ}\right.$, $\left.\alpha_{95}=7.5^{\circ}\right)$. Comparison of dispersion of the sitemeans shows a statistically significant increase in precision parameter, $k$, after tilt corrections are made, according to the test of McElhinny [8] (Table 1). We note that the arguments presented by $\mathrm{McF}$ adden and Jones [9] regarding the $f$-ratio criteria indicate that the fold test by McElhinny's method makes a conservative estimate of probability. This positive fold test confirms that the ChRM directions are of late Cretaceous to early Tertiary origin.

Sichuan. Four specimens were cut from each hand sample from the Xiaaba and Leidashu Formations for measurement. The orientation of one block sample was lost during processing and this sample is therefore not considered further. NRM intensities are more variable than in the upper Cretaceous rocks from Nanjing, ranging from $10^{-1}$ $\mathrm{A} / \mathrm{m}$ to $10^{-4} \mathrm{~A} / \mathrm{m}$, the lower yalues usually in coarser-grained to pebble-bearing samples. The more weakly magnetized samples were measured on a cryogenic magnetometer. Typical NRM demagnetograms are shown in Fig. 2c, d.

Most specimens display relatively straightforward demagnetization behavior, characterized by a single linear trajectory over a broad temperature range from $200^{\circ}$ to $675^{\circ} \mathrm{C}$. The direction of magnetization is usually northerly (Fig. 2c) but in two samples it is approximately antipodal and southerly (e.g., Fig. 2d). The fact that the magnetizations persist to temperature treatments of up to $675^{\circ} \mathrm{C}$ again indicates that hematite is most probably the carrier of what we consider to be the characteristic component. 
TABLE 1

Characteristic site-mean directions for upper Cretaceous rocks near Nanjing

\begin{tabular}{|c|c|c|c|c|c|c|c|c|}
\hline \multirow[t]{2}{*}{ Site } & \multirow[t]{2}{*}{$\mathrm{Sa}$} & \multicolumn{3}{|l|}{ In situ } & \multicolumn{2}{|c|}{ Tilt corrected } & \multicolumn{2}{|l|}{ VGPs } \\
\hline & & $D\left(^{\circ}\right)$ & $\left.10^{\circ}\right)$ & $\alpha_{95}\left({ }^{\circ}\right)$ & $D\left({ }^{\circ}\right)$ & $I\left(^{\circ}\right)$ & lat. $\left({ }^{\circ} \mathrm{N}\right)$ & long. $\left({ }^{\circ} \mathrm{E}\right)$ \\
\hline NKA & $5 / 5$ & 331.6 & 21.4 & 9.7 & 0.4 & 64.4 & 75.8 & 120.1 \\
\hline NKB & $5 / 5$ & 345.2 & 13.4 & 5.9 & 1.8 & 45.8 & 85.0 & 280.5 \\
\hline NKC & $3 / 5$ & 359.6 & 17.0 & 25.5 & 28.4 & 65.6 & 63.3 & 164.4 \\
\hline NKF & $5 / 5$ & 338.9 & 24.5 & 12.1 & 340.9 & 57.5 & 73.2 & 55.7 \\
\hline NKG & $5 / 5$ & 351.2 & 15.5 & 14.1 & 5.9 & 52.8 & 84.8 & 192.0 \\
\hline NKH & $3 / 5$ & 288.9 & 38.6 & 19.4 & 48.3 & 64.1 & 50.6 & 174.1 \\
\hline NKI & $4 / 5$ & 306.1 & 34.1 & 20.7 & 28.7 & 53.5 & 65.9 & 196.3 \\
\hline NKJ & $4 / 5$ & 338.2 & 6.2 & 16.3 & 5.8 & 46.2 & 83.3 & 249.1 \\
\hline NKK & $5 / 5$ & 335.7 & 26.6 & 20.4 & 34.5 & 56.6 & 61.3 & 189.0 \\
\hline NKL & $4 / 5$ & 327.4 & 29.2 & 22.4 & 14.3 & 60.1 & 75.4 & 166.8 \\
\hline \multicolumn{9}{|l|}{ Means: } \\
\hline 10 sites & & $333.9^{\circ}$ & $23.8^{\circ}$ & & $13.7^{\circ}$ & $58.0^{\circ}$ & $76.3^{\circ}$ & $172.6^{\circ}$ \\
\hline (43 samples) & \multicolumn{4}{|c|}{$\begin{array}{l}k_{1}=15.3 \\
\alpha_{95}=12.8^{\circ}\end{array}$} & \multicolumn{2}{|c|}{$\begin{array}{l}k_{2}=41.6 \\
\alpha_{95}=7.6^{\circ}\end{array}$} & \multicolumn{2}{|c|}{$\begin{array}{l}K=22.9 \\
A_{95}=10.3^{\circ}\end{array}$} \\
\hline
\end{tabular}

Sa is number of samples with acceptable data to number of samples analyzed at each site; $D$ and $I$ are declination and inclination. respectively; $\alpha_{95}$ is radius of cone of $95 \%$ confidence on within-site and overall means; VGPs are virtual geomagnetic north poles calculated for site-means after tilt corrections; $k_{1}$ and $k_{2}$ are Fisher precision parameters before and after tilt corrections respectively, of site-mean directions; $K$ and $A_{95}$ are Fisher statistical parameters for mean of site VGPs.

The direction of the characteristic component in each specimen was determined by principal component analysis over a minimum of three data points and these directions were averaged as unitvectors for each block sample. The magnetizations of specimens from 4 samples, corresponding to the

TABLE 2

Characteristic sample-mean directions for upper Cretaceous/lower Tertiary rocks in western Sichuan

\begin{tabular}{|c|c|c|c|c|c|c|c|c|}
\hline \multirow[t]{2}{*}{$\mathrm{Sa}$} & \multirow[t]{2}{*}{$\mathrm{Sp}$} & \multicolumn{3}{|l|}{ In situ } & \multicolumn{2}{|c|}{ Tilt corrected } & \multicolumn{2}{|l|}{ VGPs } \\
\hline & & $\overline{D\left({ }^{\circ}\right)}$ & $I\left({ }^{\circ}\right)$ & $\alpha_{95}\left({ }^{\circ}\right)$ & $\overline{D\left({ }^{\circ}\right)}$ & $I\left({ }^{\circ}\right)$ & lat. $\left({ }^{\circ} \mathrm{N}\right)$ & long. $\left({ }^{\circ} \mathrm{E}\right)$ \\
\hline $1 \mathrm{M}$ & 4 & 163.1 & -4.7 & 5.6 & 163.7 & -7.3 & 62.3 & 319.4 \\
\hline $3 \mathrm{M}$ & 4 & 359.2 & 6.5 & 6.3 & 1.0 & 19.4 & 73.5 & 278.9 \\
\hline $5 \mathrm{M}$ & 4 & 353.4 & 36.6 & 9.7 & 352.9 & 41.6 & 83.1 & 352.1 \\
\hline $6 \mathrm{M}$ & 4 & 177.0 & -13.1 & 6.5 & 178.4 & -17.7 & 72.5 & 287.6 \\
\hline $10 \mathrm{M}$ & 4 & 351.9 & 26.9 & 1.7 & 3.7 & 33.0 & 81.2 & 258.6 \\
\hline $11 \mathrm{M}$ & 4 & 38.5 & 13.4 & 6.9 & 30.4 & 37.0 & 61.6 & 197.7 \\
\hline $12 \mathrm{M}$ & 4 & 11.9 & -8.6 & 6.1 & 6.7 & 29.3 & 77.5 & 251.1 \\
\hline $13 \mathrm{M}$ & 4 & 12.6 & 19.9 & 1.2 & 345.7 & 44.7 & 78.1 & 14.5 \\
\hline $14 \mathrm{M}$ & 4 & 342.3 & 23.7 & 9.2 & 345.6 & 31.4 & 73.6 & 339.7 \\
\hline $15 \mathrm{M}$ & 4 & 342.2 & 23.8 & 17.8 & 343.0 & 44.7 & 74.8 & 15.5 \\
\hline $16 \mathrm{M}$ & 4 & 23.2 & 10.1 & 4.6 & 359.4 & 30.0 & 79.6 & 285.5 \\
\hline $17 \mathrm{M}$ & 4 & 26.5 & 9.0 & 4.7 & 0.2 & 34.2 & 82.3 & 280.9 \\
\hline \multicolumn{9}{|c|}{ Means: } \\
\hline \multicolumn{2}{|c|}{12 samples } & $3.8^{\circ}$ & $15.7^{\circ}$ & & $357.6^{\circ}$ & $31.6^{\circ}$ & $80.8^{\circ} \mathrm{N}$ & $296.8^{\circ} \mathrm{E}$ \\
\hline \multicolumn{2}{|c|}{ (48 specimens) } & \multicolumn{2}{|c|}{$\begin{array}{l}k_{1}=14.1 \\
\alpha_{95}=12.0^{\circ}\end{array}$} & & \multicolumn{2}{|c|}{$\begin{array}{l}k_{2}=26.7 \\
\alpha_{95}=8.6^{\circ}\end{array}$} & \multicolumn{2}{|c|}{$\begin{array}{l}K=32.6 \\
A_{95}=7.7^{\circ}\end{array}$} \\
\hline
\end{tabular}

Sa is sample, 1 per site, from which $\mathrm{Sp}$, the number of specimens were measured; $D$ and $I$ are declination and inclination, respectively; $\alpha_{95}$ is radius of cone of $95 \%$ confidence on within-sample and overall means; VGPs are virtual geomagnetic north poles calculated for sample-means after tilt corrections; $k_{1}$ and $k_{2}$ are Fisher precision parameters before and after tilt corrections, respectively, of sample-mean directions; $K$ and $A_{95}$ are Fisher statistical parameters for probable mean of sample VGPs. 
most weakly magnetized, gave erratic demagnetizations and internally inconsistent directions; data from these samples were therefore rejected. The distribution of ChRM directions for the 12 accepted samples is shown in Fig. 3 (bottom).

There is an improvement in grouping of the directions (adjusted to common polarity) after tilt correction, although the increase in precision parameter $\left(k_{2} / k_{1}=1.89\right)$ is not quite significant at the $95 \%$ confidence level (test value $=2.05$ for $N=12$ ) according to the conservative method of McElhinny [8]. Dispersion is, however, decreased significantly after tilt correction for a subset of data that includes only the 10 samples with northerly directions, perhaps because the bedding tilts at the 2 samples with southerly directions are very small, less than $10^{\circ}$. In any case, the high stability of the ChRMs, their deviation from the present field direction before tilt correction and tendency to group better after tilt correction, as well as the presence of opposite polarities, together suggest that these magnetizations were acquired early, most likely before tectonic tilting in the Paleogene. Nevertheless, it is not clear how representative are these results of the late Cretaceous paleomagnetic field for western Sichuan because of the limited data set consisting of 48 specimen directions from only 12 samples.

\section{Paleomagnetic poles}

The site-mean ChRM directions converted to virtual geomagnetic poles (VGPs) for the upper Cretaceous Puko and Yanzijing Formations of Nanjing give a mean paleopole position at $76.3^{\circ} \mathrm{N}$ lat., $172.6^{\circ} \mathrm{E}$ long., $A_{95}=10.3^{\circ}$ (Table 1, Fig. 4). The previous Cretaceous pole [4] for South China (Canton, Hubei and Yunnan provinces) is at $59^{\circ} \mathrm{N}$, $158^{\circ} \mathrm{E}\left(A_{95}=8^{\circ}\right)$, in the general vicinity of, but significantly different from our determination. Because this early result is not based on demagnetization analysis, we regard it as superceded by our present result. We note that the upper Cretaceous paleopole position we now obtain is not significantly different from late Cretaceous mean poles from Western Europe, North China, Siberia, and the Russian platform individually, or collectively as a Eurasian mean $\left(72.5^{\circ} \mathrm{N}, 177.5^{\circ} \mathrm{E} ; A_{95}=6.8^{\circ}\right.$ [3]). This supports the proposal of Achache et al. [3] that South China was sutured to Eurasia by the

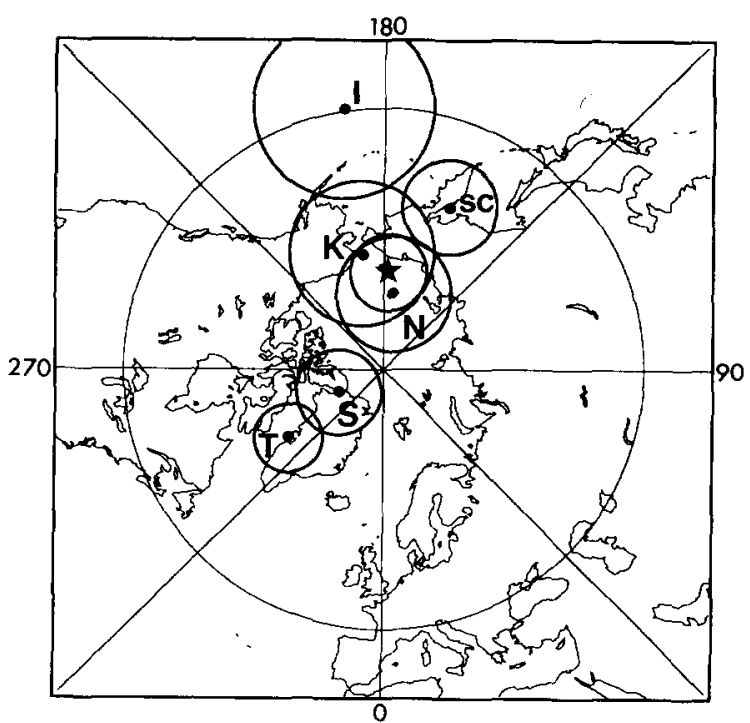

Fig. 4. Late Cretaceous paleomagnetic poles (with associated circles of $95 \%$ confidence) representative of some parts of Eurasia. Pole shown by star (Eurasia mean) and poles labeled $I$ (Indochina) and $T$ (Southern Tibet) from tabulation in [3]. Pole $S C$ is previous Cretaceous pole from South China [4]; pole $K$ is Cretaceous pole from South Korea [10]; poles $N$ (Nanjing area) and $S$ (western Sichuan) are reported here.

end of the Cretaceous and at least this part of South China did not experience any paleomagnetically significant relative latitudinal or local rotational movement since that time. We also note that the Nanjing pole, although more northerly and easterly, is not significantly different from a paleopole $\left(68.9^{\circ} \mathrm{N}, 191.0^{\circ} \mathrm{E} ; A_{95}=12.7^{\circ}\right.$; Fig. 4) reported from the Gyeongsang Supergroup of South Korea which spans the Cretaceous [10].

In contrast, the paleomagnetic pole for the upper Cretaceous to lower Paleocene rocks we studied in western Sichuan $\left(80.8^{\circ} \mathrm{N}, 296.8^{\circ} \mathrm{E} ; A_{95}\right.$ $=7.7^{\circ}$, based on 12 sample VGPs; Table 2) is significantly different at the $95 \%$ confidence level from both the Nanjing upper Cretaceous pole we obtained as well as the Eurasia mean late Cretaceous pole [3] (Fig. 4). Calculated according to the method described in [3], the western Sichuan paleomagnetic data indicate a paleolatitude of 17 $\pm 7.7^{\circ} \mathrm{N}$, which is $13 \pm 10.3^{\circ}$ more southerly than the paleolatitude of $30 \pm 6.8^{\circ} \mathrm{N}$ predicted for the locality from the Eurasia late Cretaceous reference paleopole. In addition, the declination observed $\left(357.6 \pm 8.1^{\circ}\right)$ is $22 \pm 11.2^{\circ}$ more counterclock- 
wise than that predicted by the Eurasia reference pole $\left(19.6 \pm 7.8^{\circ}\right)$. At face value, the limited paleomagnetic data from western Sichuan would therefore suggest that this area translated $1440 \pm$ $1140 \mathrm{~km}$ northward and rotated $22 \pm 11.2^{\circ}$ counterclockwise relative to Eurasia since the late Cretaceous to early Tertiary. A tectonic interpretation of these results is offered below but we again stress that the relatively small number of independently oriented samples we had available for analysis makes any conclusions highly tentative.

According to the tectonic model of Molnar and Tapponnier [1], India has penetrated about 2000 $\mathrm{km}$ into Asia, with much of the deformation of the Asian continental lithosphere taken up by lateral strain through strike-slip faulting on such major left-lateral faults as the Altyn Tagh, Kunlun, Kang Ting and the early Red River (Fig. 1). In further elaborations of this Tertiary tectonic model, Indochina and subsequently southern China are shown to experience clockwise rotation as successive phases of continental extrusion are thought to proceed [11]. This is opposite to the counterclockwise sense of rotation inferred from the western Sichuan paleomagnetic results. However, given the confined sampling area, the western Sichuan results may well reflect only localized block rotations, perhaps related more to proximity to the left-lateral Kang Ting shear zone, rather than representative of a larger tectonic domain. More extensive paleomagnetic sampling is also needed to substantiate the apparently more southerly origin of at least this part of South China. The present limited data would lead us to believe that western Sichuan experienced in the Tertiary an amount of relative northward motion $\left(13 \pm 10.3^{\circ}\right)$ closer to that calculated for southern Tibet $\left(17 \pm 7.5^{\circ}\right)$ $[3,12]$ than the statistically insignificant amount determined for Indochina $\left(5.5 \pm 10.2^{\circ}\right)$ [3], as if it was pushed ahead of the impinging India indentor.

\section{Acknowledgements}

This work is part of a cooperative scientific program between Academia Sinica, LamontDoherty Geological Observatory and the Univer- sity of Florida. Thanks are extended to Dr. Ma Ruishi and others from the Department of Geology, Nanjing University, and Mr. Tang Ruolong and others from the Pan-Xi Geological Brigade, Sichuan Geological Bureau, for their field assistance. Laboratory work was supported by the National Science Foundation, grant EAR83-13578. Lamont-Doherty Geological Observatory Contribution No. 3991.

\section{References}

1 P. Molnar, and P. Tapponnier, Cenozoic tectonics of Asia: effects of a continental collision, Science 189, 419-426, 1975.

2 P. Tapponnier, and P. Molnar, Active faulting and Cenozoic tectonics of China, J. Geophys. Res. 82, 2905-2930, 1977.

3 J. Achache, V. Courillot and J. Besse, Paleomagnetic constraints on the late Cretaceous and Cenozoic tectonics of southeastern Asia, Earth Planet. Sci. Lett. 63, 123-136, 1983.

4 C.T. Lee, H.M. Lee, H.S. Liu, C. Liu and S.J. Ye, Preliminary study of Paleomagnetism of some Mesozoic and Cainozoic redbeds of South China, Acta Geol. Sinica 43, 241-246, 1963 (English translation (T\&C) by Directorate of Scientific Information Services, DRB, Canada, 1966).

5 Compiling Group of Regional Stratigraphic Table of Sichuan Province, The Regional Stratigraphic Table of Southwest China (Sichuan Province), Geological Publishing House, Beijing, 1978.

$6 \mathrm{Y} . \mathrm{Li}$, On the negation of Sichuanian movement, Sci. Geol. Sinica 4, 374-377, 1979

7 J.L. Kirschvink, The least-squares line and plane and the analysis of palaeomagnetic data, Geophys. J. R. Astron. Soc. 62, 699-718, 1980.

8 M.W. McElhinny, Statistical significance of the fold test in palaeomagnetism, Geophys. J. R. Astron. Soc. 8, 338-340. 1964.

9 P.L. McFadden and D.L. Jones, The fold test in palaeomagnetism, Geophys. J. R. Astron. Soc. 67, 53-58, 1981.

10 Y. Otofuji, J.Y. Oh, T. Hirajima, K.D. Min and S. Sajima, Paleomagnetism and age determination of Cretaceous rocks from Gyeongsang Basin, Korean Peninsula, in: The Tectonic and Geological Evolution of Southeast Asian Seas and Islands, Part 2, Am. Geophys. Union, Geophys. Monogr. Ser. 27, 388-396, 1982.

11 P. Tapponnier, G. Peltzer, A.Y. Le Dain and R. Armijo, Propagating extrusion tectonics in Asia: new insights from simple experiments with plasticine, Geology 10, 611-616, 1982.

12 J. Achache, V. Courtillot and Y.X. Zhou, Paleogeographic and tectonic evolution of southern Tibet since middle Cretaceous time: new paleomagnetic data and synthesis, J. Geophys. Res. 89, 10,311-10,339, 1984. 